\title{
PSYCHOMOTOR EVALUATION OF ATHLETE AND NON-ATHLETE CHILDREN
}

\author{
Dan Alexandru SZABO ${ }^{1 *}$, Nicolae NEAGU ${ }^{1}$, Mariana ARDELEAN ${ }^{1}$, Ioan Sabin SOPA ${ }^{2}$ \\ 1 “George Emil Palade” University of Medicine, Pharmacy, Science, and Technology of Târgu Mureş, Faculty \\ of Medicine, Târgu Mureş, Romania \\ 2 “Lucian Blaga" University Sibiu, Faculty of Science, Sibiu, Romania \\ *Corresponding author: dan-alexandru.szabo@umfst.ro
}

https://doi.org/10.35189/dpeskj.2020.59.1.6

\begin{abstract}
Throughout the centuries, the humankind has been driven towards knowledge. Therefore, people have taken interest in how the human mind interacts with the body. Nowadays, this relation is better understood than any time before. Child development must work as a symbiosis between the psychic and physical aspects. Latency of one of these elements may lead to serious problems in other periods of life. This study included 26 children, boys and girls, all having roughly the same age. They provided us with important data about their psychomotor development with the help of two tests. The aim of the research was to investigate how these children would perform the tests, to reflect their psychomotor ability and ultimately to build up their profiles. The research methods used in this investigation were the Matorin Test and the Space Perception and Dynamic Balance Test. The results of the research have shown that the level of psychomotor ability of the tested subjects is insufficient due to deviations from the Space Perception and Dynamic Balance Test. The conclusions have highlighted that assessing the psychomotor development of the 6th-grade students, girls and boys, through the Matorin Test and the Space Perception and Dynamic Balance Test can determine the level of psychomotor and health development.
\end{abstract}

Keywords: space perception, dynamic balance, body movement, psychomotor assessment.

\section{Introduction}

There are studies that present the association between a low psychomotor and neuronal level such as epilepsy in both children and adults. Cognitive delay and delay in psychomotor development are a less researched field of epilepsy complications, but these two delays seem to be present in adults with chronic epilepsy (Garcia-Ramos, 2018). Psychomotor education is a vital component of the general education process, not only in physical and sporting education. As a result of investigations and scientific papers (Costa et al., 2015; Fisher et al., 2005; Gallahue \& Ozmun, 2002) about educational establishments, we have found that the time spent on psychomotor activities is low.

Many studies (Lubans et al., 2010; Epuran, 2011; Guralnik et al., 2010) have shown that, in the age period between 13 and 14 years, the acquired motor skills have exacerbated stability, new movements being retained very easily in the "motor memory". If an appropriate environment is provided, children in this age range learn, absorb and store a vast amount of information of any type in a very short time. This plasticity must be capitalized on by wellstructured principles and methods.

Motor ability, in general, is made up of three hierarchical components, depending on their complexity. 
Motor acts are the simplest expression of the individual's adaptive responses to concrete situations, from the need for dialogue with nature, with others or with oneself (Epuran, 2011). In other words, the motor act is the basis of motor actions or the element of which motor actions are built.

Motor acts can also be found as motor gestures. Motor actions are the syntax of motor actions that respond to the solving of an immediate task (Epuran, 2011). They form the content of motor activities. It should be emphasized that motor actions have a specific character that is detailed in terms of the conditions in which they take place.

Psychomotricity clearly means combining motor functions with psychic functions, which are mediated by the development of the nervous system. This term "psychomotor" was first introduced by Leonardo Landois in 1872. In its sphere of influence, it encompasses a multitude of particular elements such as the psyche, human body, spatial and temporal coordinates, memory, etc.

To perform movements, an individual needs a set of information according to the environment in which they are. This information is acquired through three different analyzers: the visual analyzer, the auditory analyzer, and the mechanoreceptors found at the muscle and tendon levels. The perception of space starts from the location of everything in the environment through the visual, kinesthetic and auditory analyzers (Radu \& Ulici, 2003). Of these, the visual analyzer is the most important one, providing the largest amount of information. Psychomotricity, as part of applied psychology, tends to study the motor functions integrated in and coordinated by psychic functions. It is recognized the idea that good body control is the first condition of good behavioral control.

Psychomotricity is a compound term that divides human movement into two fundamental components, the psychic and the motor ones. The literature often suggests the idea that psychomotricity emphasizes the important part of consciousness, placing first the perceptual process and the unity between perception and movement (Epuran, 2011).

Social interaction plays an important role in forming independent social skills and early social relationships. It also affects other developmental fields such as language and communication (Guralnick et al., 2010; Guralnick et al., 2006; Kim et al., 2017). Studies on psychomotor training for social skills or social interaction are ongoing (Cioni \& Sgandura, 2013). Psychomotor training enables children to change play through communication and interaction with other children, develops roles and rules for the self, develops an understanding of self and others, improves their communication ability and socialization skills through the process of finding pleasure, and develops self-control. It also helps to form a healthy personality through personal character-oriented behavioral experience by breaking away from a merit system that operates on fault orientation and focuses on the weakness, abnormal behavior and shortcomings of children (Cioni \& Sgandura, 2013; Kim et al., 2017).

Spatial orientation is essential for maintaining proper posture for locomotion and for most motor activities. Three different systems, namely the vestibular, visual and somatosensory ones are distinguished, which together govern these complex behaviors (Barra et al., 2010; Joassin et al., 2010).

Kinesthesia is a "muscular feel", a way to accept your own movements and positions. In another perspective, it is described as "a sense mediated by nerve endings localized in the muscles, tendons, and joints being stimulated by body movement and tensions" (Paterson, 
2012). Reaction time provides an indirect index of the processing capability of the central nervous system and a simple means of determining sensorimotor performance (Namita et al., 2010). Reaction time is the interval between the onset of a signal (stimulus) and the initiation of a movement response (Senel \& Oroglu, 2006). Movement time is the interval between the initiation and completion of the movement. Response time is the cumulative effect of reaction time as well as movement time (Mannie, 2011).

Wilson et al. (2016) demanded a stronger consideration of psychomotor factors for talent research and acknowledged that players with good psychomotor factors (e.g., technical skills) are highly coveted players.

Psychomotor performance is an important determinant of performance in sports, specifically in those requiring fast decision-making and execution skills (Tulppo et al., 2014). Also, particularly in professional sports, high strain due to the extremely busy competition schedule may result in decreased cognitive performance as an early marker of overreaching (Nederhof et al., 2006; Hynynen et al., 2008). Overreaching is a condition when "immediately after the period of overload training, performance will usually be impaired" and recovery to the normal performance level lasts days to weeks (Nederhof et al., 2007). The suggested marker of overreaching is psychomotor slowness, measured with motor time and reaction time tests (Nederhof et al., 2006; Tulppo et al., 2014).

Motor qualities are considered important for the physical, mental and social evolution of children (Gallahue \& Ozmun, 2002) and may even be the foundation of an active and healthy lifestyle as many studies have shown. For example, it has been revealed that a good index of the level of motor qualities has a positive impact on health, influencing effectively the improvement of the cardiorespiratory capacity, the maintenance of optimal body weight, the improvement of the level of practice and the daily activities, the development of the executive function of the body, etc. (Lubans et al., 2010; Fisher et al., 2005; Williams et al., 2008; Krombholz, 2013).

The purpose of the research is to provide reference values for the participating subjects, boys and girls, about their psychomotor development at the time the tests were conducted, using discriminatory criteria such as gender and level of sports activity.

A first reason for choosing this theme was the desire to understand to what extent psychomotor education is present in the instructive-educational process that takes place during physical education classes. The main objectives were to identify, using the Matorin Test and the Space Perception and Dynamic Balance Test, the psychomotor profile of the $6^{\text {th }}$ graders, girls and boys, athlete or non-athlete children.

\section{Methodology}

\section{Participants}

In the study, we investigated 26 students in the 6th grade A. The subjects were divided into four subcategories according to two criteria of discrimination, namely gender and the practice of a particular sport in an organized environment. 


\section{Instruments}

The tests applied were the following: Matorin Test and Spatial Perception and Dynamic Balance Test.

Matorin Test - the purpose of this test was to highlight the general coordination of the subjects. The test consists of a jump around one's own longitudinal axis. The subject aims to achieve the broadest rotation. The rotation was measured in degrees. The subject was asked to perform two jumps to the right and two to the left, eventually getting the best for each side. Also, a jump was not validated in case of losing one's balance or landing outside the landing area. The meaning of the first jump to the right or to the left was at the discretion of each subject. Four thin cardboard plates were used to perform this test, but they were bonded together. The size of a board was $100 \mathrm{~cm}$ x $70 \mathrm{~cm}$. The surface was graded to measure as accurately as possible the amplitude of the jump. In order not to imprint a rotational movement after the jump, the cardboard surface was stabilized by means of a resistant adhesive tape.

Spatial Perception and Dynamic Balance Test - this test was applied to investigate proprioception and spatial orientation but also to determine coordination skills and dynamic balance. The equipment needed for the test was minimal, consisting of an adhesive tape roll and a measuring object, and a roulette. The subjects had the task of moving in a straight line over a distance of 12 meters, stopping at the moment they felt they had arrived at their destination. The starting and ending points were clearly and distinctly marked, being joined by a straight line of adhesive tape traced on the floor of the hall. The subjects had to travel without support from the visual analyzer; they wore ski glasses that had been modified by applying a black foil on the viewfinder to prevent light from penetrating through the glasses and thus altering the test results. Positioned at the starting point, the subjects were asked, before putting their glasses, to visualize the route, focusing on the final point. There was no start order, the subjects starting the test at a specific time they chose. For greater accuracy of the test, the subjects were not disturbed by other sounds or other factors. The test was carried out in a sports hall measuring 38 meters in length, 18 meters in width and 7.5 meters in height. When the subject stopped, he or she was asked to stay in place to make the measurements using the roulette. Two parameters, “+”, “.-" "12 meters", and right and left side deviations were recorded. All values obtained in this test were expressed in centimeters.

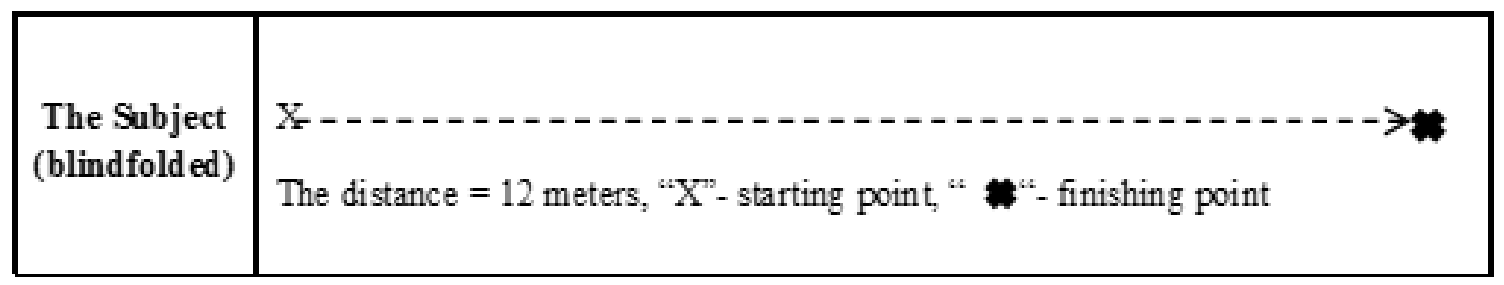

Figure 1. Representation of the Spatial Perception and Dynamic Balance Test path 


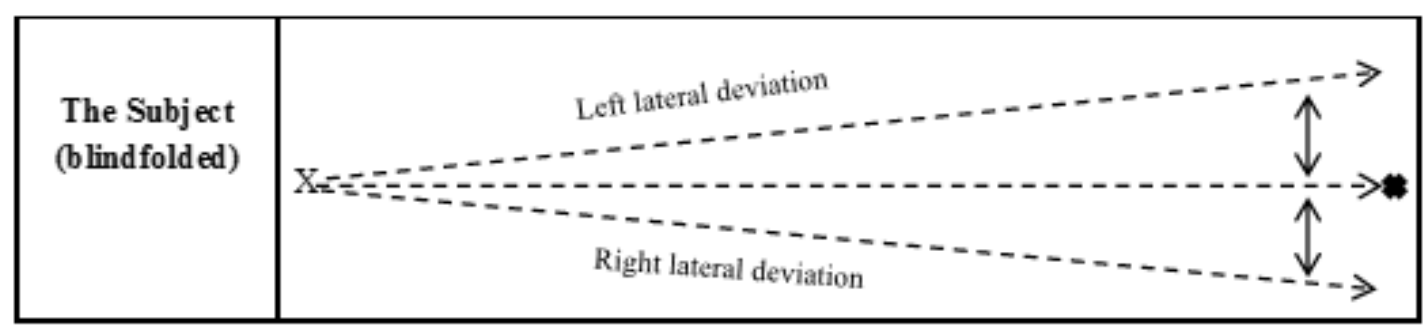

Figure 2. Representation of the lateral deviation in the Spatial Perception and Dynamic Balance Test

\section{Procedure}

The study was conducted at the "Mihai Viteazu" Middle School located in Targu Mures. The subjects were examined in a series of tests to assess the psychomotor level of each one. Prior to the test, we had provided all the necessary safety conditions. Thus, the physical education and sports teacher of the classroom where we carried out the study provided the required documentation (medical certificate), stating that the subjects involved were physically fit. The tests ensured safe conditions to perform them. This investigation was done in accordance with the Declaration of Helsinki (Harris \& Atkinson, 2013) and approved by the Ethics Committee of the "Lucian Blaga" University in Sibiu, before the commencement of the study. It also met the ethical standards for Sport and Exercise Science Research. Due to the fact that the General data protection regulation had entered into force on 25 May 2018 (Regulation (EU) 2016/679), imposing a single set of rules on the protection of personal data, the tutors of the investigated subjects were provided with an agreement for the recording and use of personal data. This agreement was signed in two copies by all tutors and allowed the recording and use of some motor parameters. Confidentiality was ensured by protecting the identity of all participants.

For the Matorin Test, the cardboard construction was placed at the center of half of the hall, away from any harsh or bumpy object (wall, gym, radiator) to avoid injuries in the event of a fall after the jump. For the Self-Impulse and Dynamic Balance Test, it was assured that the path traveled by the subject (blindfold) was free.

\section{Results}

All values recorded after the tests are shown in the table below.

Table 1. Values for the two tests

\begin{tabular}{|c|c|c|c|c|c|c|c|c|c|c|}
\hline \multicolumn{5}{|c|}{ "Mihai Viteazu" Middle School } & \multicolumn{6}{|c|}{ Tests } \\
\hline \multicolumn{5}{|c|}{ Subjects } & \multicolumn{2}{|c|}{$\begin{array}{c}\text { Matorin Test } \\
(\mathrm{UM}= \\
\text { Degrees) }\end{array}$} & \multicolumn{4}{|c|}{$\begin{array}{l}\text { Spatial Perception and Dynamic Balance Test } \\
\qquad(\mathrm{UM}=\mathrm{Cm})\end{array}$} \\
\hline No. & Subject no. & Age & $\begin{array}{l}\text { Gen } \\
\text { der }\end{array}$ & Sport & Right & Left & Dev. Left & Dev. Right & $\begin{array}{c}\text { Deviation } \\
+\end{array}$ & $\begin{array}{c}\text { Deviation } \\
-\end{array}$ \\
\hline 1 & Subject 1 & 13 & $\mathrm{~F}$ & Basketball & 355 & 330 & 64 & 0 & 70 & 0 \\
\hline 2 & Subject 2 & 13 & M & Football & 295 & 365 & 23 & 0 & 55 & 0 \\
\hline
\end{tabular}




\begin{tabular}{|c|c|c|c|c|c|c|c|c|c|c|}
\hline 3 & Subject 3 & 13 & $\mathrm{~F}$ & & 315 & 310 & 197 & 0 & 0 & 5 \\
\hline 4 & Subject 4 & 13 & M & & 360 & 355 & 74 & 0 & 0 & 3 \\
\hline 5 & Subject 5 & 12 & M & Football & 270 & 315 & 0 & 0 & 0 & 2 \\
\hline 6 & Subject 6 & 14 & M & & 310 & 405 & 38 & 0 & 200 & 0 \\
\hline 7 & Subject 7 & 12 & $\mathrm{~F}$ & Volleyball & 365 & 390 & 0 & 306 & 108 & 0 \\
\hline 8 & Subject 8 & 13 & $\mathrm{~F}$ & & 240 & 205 & 0 & 290 & 100 & 0 \\
\hline 9 & Subject 9 & 13 & M & Handball & 370 & 350 & 0 & 0 & 0 & 50 \\
\hline 10 & Subject 10 & 13 & M & & 345 & 320 & 304 & 0 & 0 & 100 \\
\hline 11 & Subject 11 & 13 & $\mathrm{~F}$ & & 325 & 320 & 50 & 0 & 0 & 45 \\
\hline 12 & Subject 12 & 13 & M & & 340 & 400 & 0 & 40 & 50 & 0 \\
\hline 13 & Subject 13 & 13 & $\mathrm{~F}$ & & 315 & 320 & 108 & 0 & 80 & 0 \\
\hline 14 & Subject 14 & 13 & $\mathrm{~F}$ & Gymnastics & 355 & 325 & 200 & 0 & 0 & 30 \\
\hline 15 & Subject 15 & 13 & $\mathrm{~F}$ & Volleyball & 320 & 255 & 0 & 253 & 200 & 0 \\
\hline 16 & Subject 16 & 13 & M & & 270 & 320 & 25 & 0 & 175 & 0 \\
\hline 17 & Subject 17 & 13 & M & & 270 & 295 & 0 & 238 & 205 & 0 \\
\hline 18 & Subject 18 & 13 & $\mathrm{~F}$ & & 260 & 280 & 0 & 325 & 0 & 290 \\
\hline 19 & Subject 19 & 13 & M & & 305 & 275 & 0 & 318 & 0 & 25 \\
\hline 20 & Subject 20 & 13 & M & Football & 340 & 320 & 0 & 110 & 0 & 3 \\
\hline 21 & Subject 21 & 13 & $\mathrm{~F}$ & & 240 & 290 & 0 & 188 & 0 & 40 \\
\hline 22 & Subject 22 & 13 & $\mathrm{~F}$ & Gymnastics & 360 & 340 & 0 & 206 & 0 & 35 \\
\hline 23 & Subject 23 & 13 & $\mathrm{~F}$ & & 340 & 315 & 60 & 0 & 80 & 0 \\
\hline 24 & Subject 24 & 13 & M & Swimming & 380 & 345 & 0 & 25 & 60 & 0 \\
\hline 25 & Subject 25 & 12 & $\mathrm{~F}$ & & 365 & 370 & 0 & 55 & 47 & 0 \\
\hline 26 & Subject 26 & 13 & $\mathrm{~F}$ & Handball & 300 & 310 & 0 & 105 & 38 & 0 \\
\hline
\end{tabular}

The statistical analysis comprised descriptive statistics (average, median, standard deviation) and inferential statistics. For the comparison of medians, the non-parametric Mann-Whitney Test was applied. The chosen significance threshold for $\mathrm{p}$ was 0.05 . The statistical analysis was performed using the GraphPad Prism software.

Table 2. Statistical results of the Matorin Test for right and left jumps according to gender criteria

\begin{tabular}{lcclcc}
\hline \multicolumn{1}{c}{ Matorin right } & $\begin{array}{c}\text { Female } \\
\text { gender }\end{array}$ & $\begin{array}{c}\text { Male } \\
\text { gender }\end{array}$ & Matorin left & $\begin{array}{c}\text { Female } \\
\text { gender }\end{array}$ & $\begin{array}{c}\text { Male } \\
\text { gender }\end{array}$ \\
\hline Number of values & 14 & 12 & Number of values & 14 & 12 \\
Mean & 318.2 & 321.3 & Mean & 311.4 & 338.8 \\
Std. Deviation & 44.14 & 39.95 & Std. Deviation & 45.63 & 39.15 \\
\hline \multicolumn{1}{c}{ P value } & \multicolumn{2}{c}{0.856} & P-value & \multicolumn{2}{c}{0.117} \\
\hline
\end{tabular}

The Mann-Whitney Test has revealed that there is no statistically significant difference between Matorin degrees left and right in female gender and male gender. 

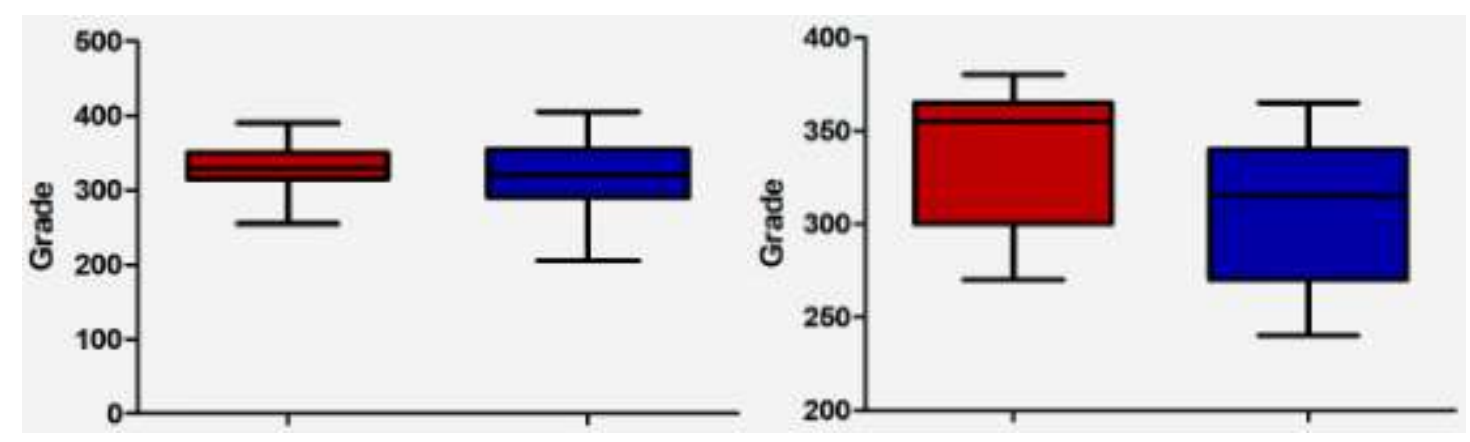

Figure 3. Matorin Test results for left jump (right side of the figure) and right jump (left side of the figure) - red color for female and blue color for male

Table 3. Statistical results of the Matorin Test for left and right jumps according to athletel non-athlete criteria

\begin{tabular}{cccccc}
\hline Matorin left & Athlete & Non-athlete & Matorin right & Athlete & Non-athlete \\
\hline Number of values & 11 & 15 & Number of values & 11 & 15 \\
Mean & 331.4 & 318.7 & Mean & 337.3 & 306.7 \\
Std. Deviation & 34.50 & 50.58 & Std. Deviation & 35.80 & 41.56 \\
\hline P value & \multicolumn{2}{c}{0.480} & P value & \multicolumn{2}{c}{0.061} \\
\hline
\end{tabular}

The Mann-Whitney Test has shown that there is no statistically significant difference between Matorin degrees left and right in athletes and non-athletes. The category of athletes included both female gender and male gender, but also non-athletes.
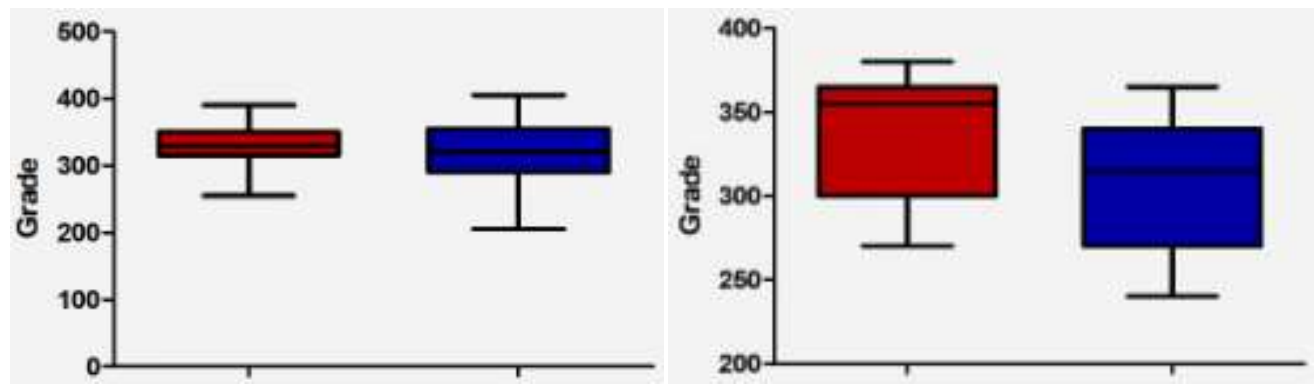

Figure 4. Matorin Test results for left jump (left side of the figure) and right jump red color for athletes and blue color for non-athletes

Table 4. Statistical results of the Space Perception and Dynamic Balance Test, right and left side deviations according to gender criteria

\begin{tabular}{lcc}
\hline $\begin{array}{l}\text { Space Perception Test and Dynamic Deviation Right and } \\
\text { Left }\end{array}$ & Female gender & Male gender \\
\hline Number of values & 14 & 12 \\
Mean & 171.9 & 99.58 \\
Std. Deviation & 98.46 & 118.2 \\
\hline P value & \multicolumn{2}{c}{0.101} \\
\hline
\end{tabular}


The Mann-Whitney Test has emphasized that there is no statistically significant difference between right and left deviation mean values in the Space Perception and Dynamic Balance Test performed by the female and male genders.

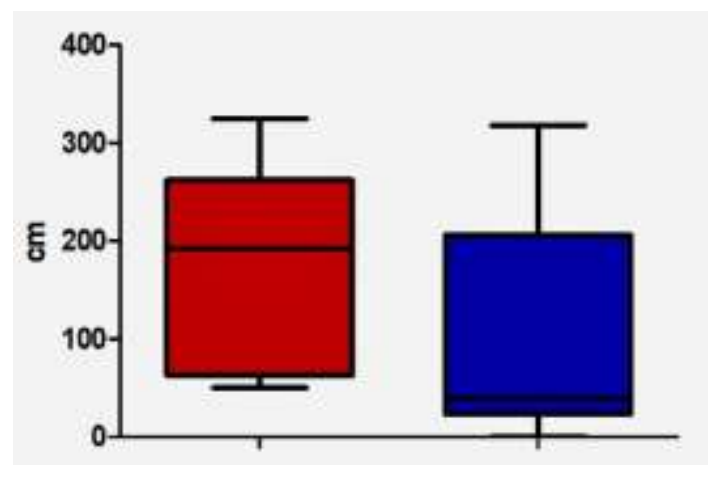

Figure 5. Space Perception and Dynamic Balance Test results, right and left side deviations according to gender criteria (red color for female, blue color for male)

Table 5. Statistical results of the Space Perception and Dynamic Balance Test, back and forth $(+/-)$ deviations according to gender criteria

\begin{tabular}{lcc}
\hline $\begin{array}{l}\text { Spatial Perception and Dynamic Balance Test, } \\
\text { back and forth deviation }\end{array}$ & $\begin{array}{c}\text { Female } \\
\text { gender }\end{array}$ & $\begin{array}{c}\text { Male } \\
\text { gender }\end{array}$ \\
\hline Number of values & 14 & 12 \\
Median & 58.50 & 52.50 \\
Mean & 83.43 & 77.33 \\
Std. Deviation & 76.18 & 75.77 \\
\hline P value & \multicolumn{2}{c}{0.738} \\
\hline
\end{tabular}

The Mann-Whitney test has indicated that there is no statistically significant difference between the values of back and forth deviations in the Spatial Perceptions and Dynamic Balance Test performed by the male and female genders.

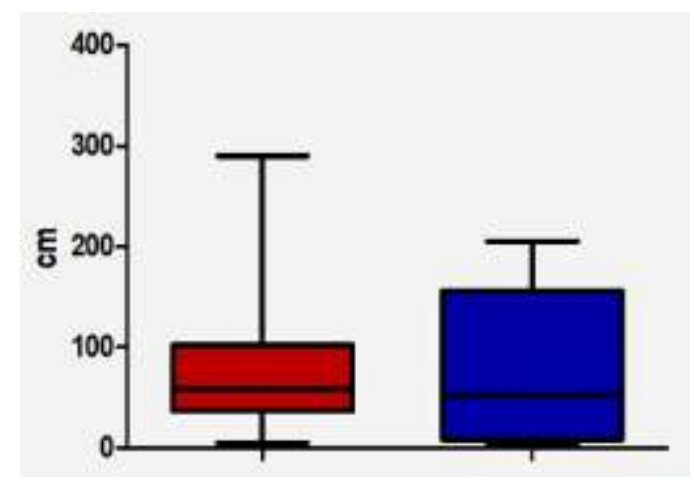

Figure 6. Spatial Perception and Dynamic Balance Test results, back and forth (+/-) deviations according to gender criteria (red color for female, blue color for male) 
Table 6. Statistical results of the Space Perception and Dynamic Balance Test, right and left side deviations according to athlete/non-athlete criteria

\begin{tabular}{cccccc}
\hline $\begin{array}{c}\text { Space Perception and } \\
\text { Dynamic Balance Test, } \\
\text { deviation to the right }\end{array}$ & Athlete & $\begin{array}{c}\text { Non- } \\
\text { athlete }\end{array}$ & $\begin{array}{c}\text { Space Perception and } \\
\text { Dynamic Balance Test, } \\
\text { deviation to the left }\end{array}$ & Athlete & $\begin{array}{c}\text { Non- } \\
\text { athlete }\end{array}$ \\
\hline Number of values & 11 & 15 & Number of values & 11 & 15 \\
Median & 105.0 & 108.0 & Median & 50.00 & 80.00 \\
Mean & 117.5 & 154.0 & Mean & 59.18 & 96.33 \\
Std. Deviation & 108.0 & 116.0 & Std. Deviation & 55.45 & 84.24 \\
\hline P value & 0.391 & P value & \multicolumn{2}{c}{0.264} \\
\hline
\end{tabular}

The Mann-Whitney Test has highlighted that there is no statistically significant difference between the right and left mean deviation and back and forth mean deviation in the Space Perception and Dynamic Balance Test performed by athletes and non-athletes.
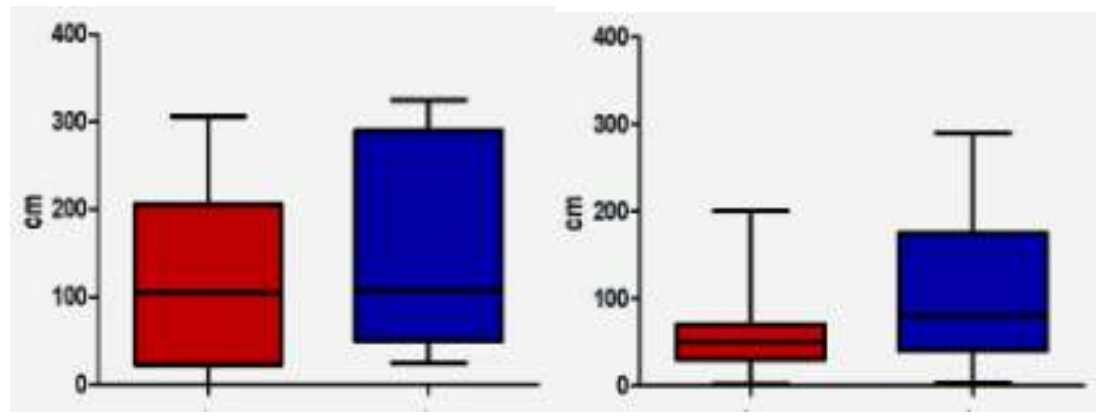

Figure 7. Statistical results of the Space Perception and Dynamic Balance Test, right side (left side of the figure) and left side deviations (red color for athletes, blue color for non-athletes)

\section{Discussion}

Mental/physical duality has been found in the scientists' works and reflections from antiquity and the Middle Ages to the present. There are studies that highlight the importance of psychomotor development for students, considering that is ensures optimal development of the components of fine motricity, such as writing (Costa et al., 2015; Gallahue \& Ozmun, 2002; Krombholz, 2013). The process of writing requires complex skills and abilities that are difficult to learn and repeat in a correct form.

The results of the investigation highlighted that, in the Matorin Test to the right, the average was 318.2 degrees for female gender and 321.3 degrees for male gender. In the same test with jump to the left, the average was 311.3 degrees for female gender and 338.8 degrees for male gender. The Mann-Whitney Test has shown that there is no statistically significant difference between degrees left and right in female gender and male gender.

The Space Perception and Dynamic Balance Test revealed an average right and left deviation from the path of $171.9 \mathrm{~cm}$ in female gender compared to male gender, who recorded a better result, only $99.58 \mathrm{~cm}$ left or right deviation. The Mann-Whitney Test has indicated that there is no statistically significant difference between the right and left deviation mean values in the Space Perception and Dynamic Balance Test performed by the female and male genders. 
In the same Dynamic Balance Test, the back and forth average deviation from the path was $83.43 \mathrm{~cm}$ for female gender compared to a better result of $77.33 \mathrm{~cm}$ for male gender. No statistically significant difference was found between the average value of the back and forth deviations from the Space Perception and Dynamic Balance Test performed by the female and male genders.

The last comparison analyzed sought to find out whether there was any statistically significant difference between athletes and non-athletes in the Space Perception and Dynamic Balance Test, left or right deviation. Regarding the deviation to the right, the average was $117.5 \mathrm{~cm}$ for the athlete category compared to the weaker result of non-athletes, $154 \mathrm{~cm}$. Concerning the deviation to the left, the average was $59.18 \mathrm{~cm}$ for the athlete category and $96.33 \mathrm{~cm}$ for non-athletes. For both results (left or right deviation), no statistically significant difference was found between athletes and non-athletes in the Space Perception and Dynamic Balance Test.

The learning and execution of these skills require a high level of symbolic and abstract thinking, intellectual activity and a high level of psychomotor development (Stănescu, 2002). Studies have highlighted the need for proper psychomotor development to prevent diseases such as epilepsy, but also to combat neurological irregularities (Piazzini, 2006). Therefore, it can be discussed not a duality in the end, but a mind/brain/body triad. Studies suggest the idea that "the psyche is intimately linked to motricity; motor and psychic phenomena divide the same neural substrate, the brain being a binder between the psychic and the body (Uner, 2007). Psychophysiological research has also substantiated the relationship between psychomotor efficiency and physiological activity (Bezanova \& Shtark, 2007).

The importance of building motor qualities is an increasingly common topic in research studies, demonstrating each time the positive effects that result from their education.

The motor ability of an individual adds up to a series of motor manifestations (skills), which, depending on their level of growth, influence the level of efficiency existing in performing a series of motor acts or actions.

In a recent study (Litwic-Kaminska, Miciej, \& Sobieralska-Michalak, 2016) researchers have discovered significant statistical differences between athlete and non-athlete children for the indicators of attention and the parameters of psychomotor reactions. In the same research, significant correlations were obtained between visual-motor coordination testing device (individuals obtained higher perceptiveness results) and the ability to focus manifested through better reaction times and fewer mistakes.

The results of earlier research indicate that sports activity has a beneficial impact on visual-motor coordination and reaction times at all ages, including adolescence (Akarsu et al., 2009; Gallota et al., 2015; Syvaoja et al., 2014; Verburgh et al., 2014).

Psychomotricity emphasizes child development. Viscione et al. (2017) believe that psychomotor education will always be an important component for achieving some progressive autonomy of the children related to the environment.

Psychomotricity has been explained and debated, from theoretical and practical points of view, as a technique that aims to form and consolidate the temper and personality, and ensure proper social integration (Shingjergji, 2014).

The educational potential of the motor activities is topical and is interesting to be studied in future educational activities. The physical exercise has passed from a performance means 
to a superior, inclusive and integrative status. At the same time, it is an educational means, a knowledge means, a recovery means, a therapeutic means, a recreational and social integration means. These multiple valences can also be found in psychomotor aspects (Talaghir \& Iconomescu, 2019).

\section{Conclusion}

The results of the investigation have shown that a profile of Matorin Test values for children aged $12.92 \pm 0.39$ years corresponding to the $6^{\text {th }}$ graders has an average of 318.2 degrees in female gender and 321.3 degrees in male gender for the jump to the right, and 311.3 degrees in female gender and 338.8 degrees in male gender for the jump to the left. Other scientific research found similar results of 319.04 degrees in male gender and 318.20 degrees in female gender for the right side and 306.17 degrees in male gender and 304.07 degrees in female gender for the left side (Păcuraru, Preda, \& Ciocoiu, 2010) or an average value of 315 degrees to the right and 305 degrees to the left (Gavojdea, 2015). In other studies regarding performance sports activities, for example in volleyball players aged between 9 and 12 years, the average result was 270.98 degrees to the left and right in the Matorin Test (Wesselly, Răchită, \& Grigoroiu-Norocel, 2015). Other research reached similar final results in a basketball sample, with 300.42 to the right and 277.7 to the left (Moldovan \& Enoiu, 2011). In a study regarding football players with ages between 10 and 12 years, the final result was 311 degrees to the left and 311.5 degrees to the right in the Matorin Test (Monea et al., 2017).

In conclusion, the main objectives of our research were fulfilled by establishing the psychomotor profile of the 6th-grade students, girls and boys, through the Matorin Test and the Space Perception and Dynamic Balance Test.

A second conclusion is that, after interpreting the results obtained, we can state that the science of psychomotricity is a fundamental and indispensable component of the instructiveeducational process. At the age of the middle-school, it must be implemented so as to ensure proper development, providing the younger student with the motor strength behind it. Based on the study, we can conclude that the level of psychomotor ability of the tested subjects is insufficient due to deviations from the Space Perception and Dynamic Balance Test.

\section{References}

Akarsu, S., Çalişkan, E., \& Dane, Ş. (2009). Athletes have faster eye-hand visual reaction times and higher scores on visuospatial intelligence than non-athletes. Turkish Journal Medicine Science, 39(6), 871-874. DOI:10.3906/sag-0809-44

Barra, J., Marquer, A., Joassin, R., Raymond, C., Chauvineau, V., \& Pérennou, D. (2010). Human use internal models to construct and update a sense of verticality. Brain: A Journal of Neurology, 133(12), 3552-3563. DOI:10.1093/brain/awq311

Bazanova, O. M., \& Shtark, M. B. (2007). Biofeedback in optimizing psychomotor reactivity: I. Comparison of biofeedback and common performance practice. Human Physiology, 33, 400-408. DOI:10.1134/S0362119707040044

Cioni, G., \& Sgandurra, G. (2013). Normal psychomotor development. Handbook of Clinical Neurology, 111, 3-15. doi:10.1016/B978-0-444-52891-9.00001-4 
Costa, H. J. T., Abelaires-Gomez, C., Arufe-Giraldez, Pazos, C., \& Furelos, R. B. (2015). Influence of a physical education plan on psychomotor development profiles of preschool children. Journal of Human Sport and Exercise, 10(1), 126-140. DOI: 10.14198/jhse.2015.101.11

Epuran, M. (2011). Motricitate şi psihism în activităţile corporale [Motricity and psychism in bodily activities]. Bucureşti: FEST.

Fisher, A., Reilly, J. J., Kelly, L. A., Montgomery, C., Williamson, A., \& Paton, J. Y. (2005). Fundamental movement skills and habitual physical activity in young children. Medicine \& Science in Sports \& Exercise, 37(4), 684-688. DOI:10.1249/01.mss.0000159138.48107.7d

Gallahue, D. L., \& Ozmun, J. C. (2002). Motor development: A theoretical model. Understanding motor development: Infants, children, adolescents, adults (5th ed.). New York: McGraw-Hill.

Gallotta, M., Emerenziani, G., Franciosi, E., Meucci, M., Guidetti, L., \& Baldari, C. (2015). Acute physical activity and delayed attention in primary school students. Scandinavian Journal of Medicine \& Science in Sport, 25(3), 331-338. DOI:10.1111/sms.12310

Garcia-Ramos, C., Dabbs, K., Meyerand, E., Prabhakaran, V., Hsu, D., Jones, J., ... Hermann, B. (2018). Psychomotor slowing is associated with anomalies in baseline and prospective large scale neural networks in youth with epilepsy. Neuroimage Clinics Journal, 19, 222231. DOI:10.1016/j.nicl.2018.04.020

Gavojdea, A. M. (2015). Study regarding balance in 9-10 years old gymnasts. The European Proceedings of Social \& Behavioural Sciences EpSBS, 11(1), 218-225. http://dx.doi.org/10.15405/epsbs.2016.06.30

Guralnick, M. J. (2010). Early intervention approaches to enhance the peer-related social competence of young children with developmental delays: a historical perspective. Infants Young Child Journal, 23(2), 73-83. DOI: 10.1097/IYC.0b013e3181d22e14

Guralnick, M. J, Connor R. T, Neville B, \& Hammond M. A. (2006). Promoting the peerrelated social development of young children with mild developmental delays: Effectiveness of a comprehensive intervention. American Journal of Mental Retardation, 111(5), 336-356. DOI: 10.1352/0895-8017(2006)111[336:PTPSDO]2.0.CO;2

Harriss, D. J., \& Atkinson, G. (2013). Ethical standards in sport and exercise science research: 2014 update. International Journal of Sports Medicine, 34, 1025-1028. DOI: $10.1055 / \mathrm{s}-0033-1358756$

Hynynen, E., Uusitalo, A., Konttinen, N., \& Rusko, H. (2008). Cardiac autonomic responses to standing up and cognitive task in overtrained athletes. International Journal of Sports Medicine, 29, 552-558. DOI: 10.1055/s-2007-989286

Joassin, R., Bonniaud, V., Barra, J., Marquer, A., \& Perennou, D. (2010). Somaesthetic perception of the vertical in spinal cord injured patients: A clinical study. Annals of Physical and Rehabilitation Medicine, 53(9), 568-574. DOI: 10.1016/j.rehab.2010.07.005

Kim, D. J., Kim, J. H., So, W. Y., \& Choi, E. J. (2017). The effects of a psychomotor training program on physical coordination in children with development delay. Iran Journal of Public Health, 46(6), 860-862. PMCID: PMC5558085

Krombholz, H. (2013). Motor and cognitive performance of overweight preschool children. Perceptual Motor Skills, 116(1), 40-57. DOI: 10.2466/22.25.PMS.116.1.40-57

Litwic-Kaminska, K., Miciej, M., \& Sobieralska-Michalak, K. (2016). Attention and psychomotor reactions among students from sport and non-sport classes. Polish Jurnal of Sports Medicine, 32(4), 123-131. DOI: 10.5604/1232406X.1218469

Lubans, D. R., Morgan, P. J., Cliff, D. P., Barnett, L. M., \& Okely, A. D. (2010). Fundamental movement skills in children and adolescents: Review of associated health benefits. Sports Medicine, 40(12), 1019-1035. doi: 10.2165/11536850-000000000-00000 
Mannie, K. (2001). Improving quickness response time. Retrieved from http://findarticles.com/p/articles/mi_m0FIH/is_9_70/ai_n18611822/

Moldovan, E., \& Enoiu, R. (2011). Study regarding psychomotricity and its role in the sporting preparation process of the basketball player. Bulletin of the Transilvania University of Braşov, Series VIII: Art, Sport, 4(53), 137-146. Retrieved from: http://webbut.unitbv.ro/BU2011/Series\%20VIII/BULETIN\%20VIII/S_05_Moldovan_Ele na-sport.pdf

Monea, D., Prodan, R., Ștefănescu, H., \& Grosu, V. (2017). Skill development using football specific methods and tests for 10-12 year old children. Studia UBB Educatio Artis Gymnasium, 62(1), 25-39. DOI:10.24193/subbeag.62(2).12

Namita, R. D. P., \& Shenvi, D. N. (2010). Effect of shift working in reaction time in hospital employees. Indian Journal of Physiology and Pharmacology, 54, 289-293. PMID: 21409868

Nederhof, E., Lemmink, K. A., Visscher, C., Meeusen, R., \& Mulder, T. (2006). Psychomotor speed: Possibly a new marker for overtraining syndrome. Sports Medicine, 36, 817-828. DOI: 10.2165/00007256-200636100-00001

Nederhof, E., Lemmink, K., Zwerver, J., \& Mulder, T. (2007). The effect of high load training on psychomotor speed. International Journal of Sports Medicine, 28, 595-601. DOI: $10.1055 / \mathrm{s}-2007-964852$

Paterson, M. (2012). Movement for movement's sake? On the relationship between kinaesthesia and aesthetics. Essays in Philosophy, 13(2), 471-497. DOI: http://dx.doi.org/10.7710/1526-0569.1433

Păcuraru, A., Preda, C., \& Ciocoiu, L. (2010). Comparative study on the coordinative ability of primary school. Bulletin of the Transilvania University of Braşov, 3(52), 125-128.

Retrieved from

http://webbut.unitbv.ro/BU2010/Series\%20VIII/BULETIN\%20VIII\%20PDF/SPORT\%20 STUDIES/12_Pacuraru\%20A.pdf

Piazzini, A., Turner, K., Chifari, R., Morabito, A., Canger, R., \& Canevini, M. P. (2006). Attention and psychomotor speed decline in patients with temporal lobe epilepsy: A longitudinal study. Epilepsy Reseach, 72(2-3), 89-96. DOI: 10.1016/j.eplepsyres.2006.04.004

Radu, I., \& Ulici, G. (2003). Evaluarea şi educarea psihomotricităţii copiilor cu dificultăţi de integrare [Psychomotricity assessment and education in children with integration difficulties]. Bucureşti: Semne.

Senel, O., \& Eroglu, H. (2006). Correlation between reaction time and speed in elite soccer players. Journal of Exercise Science Fitness, 4(2), 126-130. Retrieved from http://citeseerx.ist.psu.edu/viewdoc/download?doi=10.1.1.561.2453\&rep=rep1\&type=pdf

Shingjergji, A. (2014). Psycho-motor education of the pre-school children: A possibility for qualitative training. International Letters of Social and Humanistic Sciences, 6, 74-80. https://doi.org/10.18052/www.scipress.com/ILSHS.17.74

Stănescu, M. (2002). Educaţia fizică pentru preşcolari şi şcolari mici. O abordare psihomotrică [Physical education for preschoolers and younger schoolchildren. A psychomotor approach]. Bucureşti: Semne.

Syväoja, H., Tammelin, T., Ahonen, T., Kankaanpää, A., \& Kantomaa, M. (2014). The associations of objectively measured physical activity and sedentary time with cognitive functions in school-aged children. Plos ONE, 9(7), 1-10. doi: 10.1371/journal.pone. 0103559

Talaghir, L. G., \& Iconomescu, T. M. (2019). Study regarding psychomotor aspects approached by Romanian authors. Journal of Physical Education and Sport, 19(6), 2297 2304. DOI: 10.7752/jpes.2019.s6347 
Tulppo, M. P., Jurvelin, H., Roivainen, E., Nissila, J., Hautala, A. J., \& Kiviniemi, A. M., Kiviniemi, V. J., Takala, T. (2014). Effects of bright light treatment on psychomotor speed in athletes. Front Physiology, 5, 184-189. DOI: 10.3389/fphys.2014.00184

Uner, T. (2007). The phychomotor theory of human mind. International Journal of Neuroscience, 117(8), 1109-1148. https://doi.org/10.1080/00207450600934556

Verburgh, L., Königs, M., Scherder, E., \& Oosterlaan, J. (2014). Physical exercise and executive functions in preadolescent children, adolescents and young adults: A metaanalysis. British Journal of Sport Medicine, 48(12), 973-979. DOI: 10.1136/bjsports-2012091441

Viscione, I., D'elia, F., Vastola, R., \& Sibilio M., (2017). Psychomotor assisment in teaching and educational research. Athens Journal of Education, 4(2), 169-178. https://doi.org/10.30958/aje.4-2-5

Wesselly, T., Răchită, I., \& Grigoroiu-Norocel, C. (2010). Study regarding the development of debutant volleyball players' coordinative capacity. Marathon Journal, 7(2), 297-301. Retrieved from: http://marathon.ase.ro/pdf/vol7/vol2/18\%20Teodora\%20Wesselly.pdf

Williams, H. G., Pfeiffer, K. A., O’Neill, J. R., Dowda, M., McIver, K. L., \& Brown, W. H. (2008). Motor skill performance and physical activity in preschool children. Obesity Journal, 16(6), 1421-1426. DOI: 10.1038/oby.2008.214

Wilson, R. S., James, R. S., David, G., Hermann, E., Morgan, O. J., \& Niehaus, A. C. (2016). Multivariate analyses of individual variation in soccer skill as a tool for talent identification and development: utilising evolutionary theory in sports science. Journal of Sports Sciences, 34(21), 2074-2086. DOI: 10.1080/02640414.2016.1151544 